\title{
PATTERNS OF SOIL PROCESSES ON DARK CHESTNUT SOIL UNDER CONDITIONS OF ITS USE IN THE CONDITIONS OF THE STEPPE OF UKRAINE
}

\author{
Irina Bidnyna
}

$\mathrm{PhD}$, Academic secretary, Institute of Irrigated Agriculture of the National Academy of Agrarian Sciences of Ukraine, Naddnipryanske, 73483, Kherson, Ukraine; e-mail: irinabidnina@ukr.net

\section{Olena Shkoda}

$\mathrm{PhD}$, Head of the laboratory, Institute of Irrigated Agriculture of the National Academy of Agrarian Sciences of Ukraine, Laboratory of Analytical Studies, Naddnipryanske, 73483, Kherson, Ukraine; e-mail: lenashkoda79@gmail.com

\section{Anatolii Tomnytskyi}

$\mathrm{PhD}$, Senior Researcher, Institute of Irrigated Agriculture of the National Academy of Agrarian Sciences of Ukraine, Department of Irrigated Agriculture, Naddnipryanske, 73483, Kherson, Ukraine;

e-mail: izz.ua@ukr.net

\section{Vera Borovik}

$\mathrm{PhD}$, Senior Researcher, Institute of Irrigated Agriculture of the National Academy of Agrarian Sciences of Ukraine, Breeding Department, Naddnipryanske, 73483, Kherson, Ukraine; e-mail: veraborovik@meta.ua

\section{Viktor Sharii}

PhD student, junior scientist, Institute of Irrigated Agriculture of the National Academy of Agrarian Sciences of Ukraine, Department of Marketing, innovations transfer and economic study, Naddnipryanske, 73483, Kherson, Ukraine; e-mail: viktor.sharii@ukr.net

\begin{abstract}
As a result of four-year research, the patterns of soil processes development depending on the parameters of reclamation load were established. It was established that at the end of vegetation season irrigation of crops with water with high mineralization leads to deterioration of soil structure, where the largest amount of aggregates $>10 \mathrm{~mm}(42.67 \%$ ) was observed during disk tillage (a similar trend was observed for aggregates $<0.25 \mathrm{~mm}$ ). On average, during 2016-2019, under the influence of irrigation, the transformation of the ionic composition of the aqueous extract led to a change in the chemistry of salinity from sodium chloride-sulfate to calcium-sodium sulfate in all variants, regardless of the studied factors. The most favorable conditions for the formation of the yield in the experiment were created under a differentiated system of tillage with one split for crop rotation and with the
\end{abstract}


introduction of increased doses of fertilizers, which per 1 ha of crop rotation area provided the highest productivity, which was for corn $15.49 \mathrm{t} / \mathrm{ha}$, sorghum - $8.72 \mathrm{t} / \mathrm{ha}$, wheat winter - $7.07 \mathrm{t} / \mathrm{ha}$, and only for soybeans the best conditions this year were created for 1 option - $4.27 \mathrm{t} / \mathrm{ha}$. The highest level of profitability from 1 ha of crop rotation area was obtained for the average fertilization background 2 $\left(N_{120} P_{52,5}\right)$ for differentiated tillage - 199\%, while for other tillage systems and fertilizer doses it decreased to $33-189 \%$.

Key words: soil processes, lonic-salt composition, methods of tillage, qualitative composition of soil structure, exchange cations

\section{INTRODUCTION - THE STATE OF STUDY OF THE PROBLEM}

The development of irrigated agriculture is necessary for fulfilling the requirements of the increasing global population. However, the intensification of irrigated agriculture causes the twin menace of waterlogging and soil salinization in arid and semiarid regions of the world. Waterlogging and salinization have direct and indirect effects on crops growth and yield (Singh, 2015).

Agriculture in the Steppe of Ukraine occurs with a deficit of moisture and high air temperature, hydrothermal coefficient is $0.6-0.7$, the coefficient of natural moisture is only 0.4 , so in this region irrigation is one of the important factors of intensification of agricultural production. At the same time, it is one of the most powerful anthropogenic factors by influencing the soil and removing it from the systemic balance (Ромащенко et al., 2017).

Additional moisture supply under irrigation conditions leads to a change in the nature and direction of soil processes. The definition of these processes, their patterns is an urgent problem for the development of modern irrigated agriculture (Балюк et al., 2018).

The results of studies on the evolution of dark chestnut steppe solonetzic soil under conditions of different uses and climate aridization have shown that under the influence of agricultural use, in the arable and long-term irrigated soils, the direction of soil formation processes changes. This process affects the properties of soils leading to changes in agrophysical indicators (compaction, structural state deterioration, decrease in the strength of the microstructure and the water resistance of aggregates of dark chestnut steppe soil) (Baliuk et al., 2018).

Agro ameliorative monitoring revealed that reversible and irreversible processes take place in irrigated soils (secondary salinization, salinization, flooding, destruction of macro- and microstructure, removal of organic and nutrients, еtc.) (Медведев, 2012).

\section{TASKS AND METHODS OF RESEARCH}

The aim of the research was to determine the nature and direction of changes in the properties of dark chestnut soil, the patterns of these changes under the influence of long-term irrigation and fertilizer application. The research was carried out in the area of the Ingulets irrigation system on the lands of the experimental field of the Institute of Irrigated Agriculture of NAAS in a stationary experiment, which was laid in 1971 on dark chestnut medium loamy soil. Agrotechnics of 
cultivation of the studied crops (corn, winter wheat, soybeans, sorghum) was generally accepted for the conditions of irrigation of the Southern Steppe of Ukraine. Establishment of field research and their implementation were carried out in accordance with generally accepted methods. Analysis of the ionic-salt composition of aqueous soil extract was determined by the Giedroyc method, humus content - by Tyurin, exchangeable sodium - in the extract of $1 \%$ acetic acid ammonium, flame-photometrically, exchangeable calcium and magnesium - by DSTU 26487-85 [6-8].

The Coefficient of structure is calculated by the Fageler method:

$$
K s=\frac{b-a}{b} * 100
$$

a - sludge content in\% at microaggregate analysis;

b - sludge content in\% with granulometric analysis

The Coefficient of water resistance is calculated by the the Nikolsky method:

$$
K v=\frac{\left(a * k_{1}\right)+\left(b * k_{2}\right)+\cdots+\left(n * k_{n}\right)}{A}
$$

$a, b, n$ - the number of aggregates disintegrated per minute; $k_{1}, k_{2} \ldots k_{n}$ - correction factor; $A$ is the total number of aggregates taken for analysis.

\section{RESEARCH RESULTS}

The research fields of the Institute of Irrigated Agriculture of NAAS are located in the area of the Ingulets irrigation system, the main problem of which is the low quality of irrigation water, namely - increased mineralization and unfavorable chemical composition. Observations of the chemical composition of water were conducted from 2016 to 2019 during the growing season of plants. Water sampling was performed during irrigation. On average for 2016-2019, the mineralization of irrigation water ranged from $1.538-1.697 \mathrm{~g} / \mathrm{dm}^{3}$ (Table 1).

\begin{tabular}{|c|c|c|c|c|c|c|c|c|c|}
\hline \multirow{2}{*}{$\begin{array}{l}\text { Date of } \\
\text { selection* }\end{array}$} & \multirow{2}{*}{$\mathrm{pH}$} & \multicolumn{7}{|c|}{ The content of ions, $\frac{\mathrm{mEq} / \mathrm{dm}^{3}}{\%}$} & \multirow{2}{*}{$\begin{array}{l}\text { Mineralization, } \\
\mathrm{g} / \mathrm{dm}^{3}\end{array}$} \\
\hline & & $\mathrm{CO}_{3}{ }^{2-}$ & $\mathrm{HCO}_{3}^{-}$ & $\mathrm{Cl}^{-}$ & $\mathrm{SO}_{4}^{2-}$ & $\mathrm{Ca}^{2+}$ & $\mathrm{Mg}^{2+}$ & $\mathrm{Na}^{+}$ & \\
\hline \multirow{2}{*}{ April } & \multirow{2}{*}{8.3} & \multirow{2}{*}{-} & $\underline{3.12}$ & $\underline{12.80}$ & $\underline{11.20}$ & $\underline{4.8}$ & $\underline{8.6}$ & $\underline{13.72}$ & \multirow{2}{*}{1,697} \\
\hline & & & 0.190 & 0.454 & 0.538 & 0.096 & 0.103 & 0.316 & \\
\hline \multirow{2}{*}{ May } & \multirow{2}{*}{8.1} & \multirow{2}{*}{ - } & $\underline{3.08}$ & $\underline{12.32}$ & $\underline{10.20}$ & $\underline{4.6}$ & $\underline{8.0}$ & $\underline{13.00}$ & \multirow{2}{*}{1,602} \\
\hline & & & 0.188 & 0.437 & 0.490 & 0.092 & 0.096 & 0.299 & \\
\hline \multirow{2}{*}{ June } & \multirow{2}{*}{8.0} & \multirow[b]{2}{*}{-} & $\underline{2.48}$ & $\underline{10.80}$ & $\underline{11.20}$ & $\underline{4.0}$ & $\underline{7.80}$ & $\underline{12.68}$ & \multirow{2}{*}{1,538} \\
\hline & & & 0.151 & 0.383 & 0.538 & 0.080 & 0.094 & 0.292 & \\
\hline
\end{tabular}

Table 1. Mineralization and ionic-salt composition of irrigation water on average for 2016-2019 
I. Bidnyna, O. Shkoda, A. Tomnytskyi, V. Borovik, V. Sharii: Patterns of soil processes on dark chestnut... Zbornik Veleučilišta u Rijeci, Vol. 9 (2021), No. 1, pp. 423-439

\begin{tabular}{|c|c|c|c|c|c|c|c|c|c|}
\hline July & 7.7 & - & $\frac{2.72}{0.166}$ & $\frac{10.80}{0.383}$ & $\frac{11.00}{0.528}$ & $\frac{4.2}{0.084}$ & $\frac{8.2}{0.098}$ & $\frac{12.12}{0.279}$ & 1,538 \\
\hline August & 8.2 & - & $\frac{1.96}{0.120}$ & $\frac{12.00}{0.426}$ & $\frac{11.30}{0.542}$ & $\frac{3.8}{0.076}$ & $\frac{8.6}{0.103}$ & $\frac{12.86}{0.296}$ & 1,563 \\
\hline
\end{tabular}

Note: ${ }^{*}$ - specified average data by month

The ionic-salt composition of irrigation water during the irrigation period was stable. The chemical composition of the water was anionic to sulfate-chloride, and the cationic composition to magnesium-sodium, according to DSTU 2730: 2015 Environmental protection. The quality of natural water for irrigation. Agronomic criteria.

In the chemical composition of irrigated water on average in 2016-2019, chlorides (46.34\%) and sulfates (43.29\%) of the total amount of anions predominated among the anions. Among the cations - sodium (50.98\%) and magnesium (32.16\%) of the sum of cations (Table 2).

Table 2. Irrigation assessment of irrigation water on average for 2016-2019

\begin{tabular}{|c|c|c|c|c|c|c|c|c|c|}
\hline \multirow{2}{*}{ 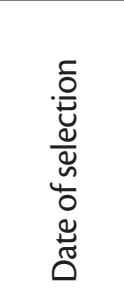 } & \multirow{2}{*}{ 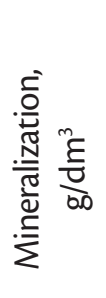 } & \multirow[b]{2}{*}{$\frac{I}{2}$} & \multirow{2}{*}{ 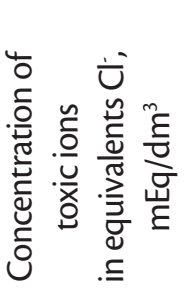 } & \multirow{2}{*}{ 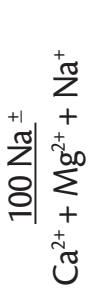 } & \multirow[b]{2}{*}{$\frac{\mathrm{Mg}^{2+}}{\mathrm{Ca}^{2+}}$} & \multirow[b]{2}{*}{$\frac{\mathrm{Ca}^{2+}}{\mathrm{Na}^{+}}$} & \multicolumn{3}{|c|}{$\begin{array}{l}\text { The content of ions, } \\
\mathrm{mEq} / \mathrm{dm}^{3}\end{array}$} \\
\hline & & & & & & & $\mathrm{CO}_{3}^{-}$ & $\mathrm{HCO}_{3}^{-}$ & $\mathrm{Cl}^{-}$ \\
\hline April & 1,697 & 8.3 & 15.21 & 50.6 & 1.8 & 0.35 & - & 3.12 & 12.80 \\
\hline May & 1,602 & 8.1 & 14.55 & 50.8 & 1.7 & 0.35 & - & 3.08 & 12.32 \\
\hline June & 1,538 & 8.0 & 13.11 & 51.8 & 2.0 & 0.32 & - & 2.48 & 10.80 \\
\hline July & 1,530 & 7.7 & 13.09 & 49.2 & 2.0 & 0.35 & - & 2.62 & 10.80 \\
\hline August & 1,563 & 8.2 & 14.16 & 50.9 & 2.3 & 0.30 & - & 1.96 & 12.00 \\
\hline Average & 1,581 & 8.1 & 13.99 & 51.0 & 1.9 & 0.33 & - & 2.62 & 11.72 \\
\hline
\end{tabular}

On average for the studied years, the content of non-toxic salts in irrigation water was $0.298 \mathrm{~g} / \mathrm{dm}^{3}$, and the content of toxic $-1.283 \mathrm{~g} / \mathrm{dm}^{3}$.

The content of toxic salts in chlorine equivalents, which characterizes the water quality at the risk of secondary salinization of the soil, averages $13.99 \mathrm{mEq} / \mathrm{dm}^{3}$ for the studied year and belongs to class II (limited suitable for irrigation). In terms of the danger of soil alkalinization, salinization and toxic effects on plants, irrigation water also belongs to the same quality class. The $\mathrm{pH}$ of the water varied from 7.7 to 8.3 .

Studies have shown that the irrigation of water of high mineralization changes the ratio of mesoaggregates of different sizes and their water resistance, but the structural and aggregate composition of the soil was also influenced by the system of tillage. 
It is established that on average for 2016-2019 for systems of long-term application of shallow tillage in crop rotation in the phase of full maturity of soybeans in the control version (option 1), a maximum content of air-dry units of $0.25-10 \mathrm{~mm}$ was in arable land layers $-61.58 \%$. The most agronomically valuable aggregates (size 1-5 mm) - 32.64\%, which on the scale of assessment of the structural and aggregate composition of soils is characterized as satisfactory. The number of block aggregates with a size of $>10 \mathrm{~mm}$ was $35.56 \%$, and soil spraying (sum of aggregates $<0.25 \mathrm{~mm}$ ) was $2.86 \%$ and reached the best value in the experiment (Table 3). Under the influence of irrigation, the coefficient of soil structure ranged from 1.2 to 1.6. The highest rate was for shelf processing (option 1) and was 1.6, which exceed s the values obtained for other options.

Also, one of the important indicators of the properties of structural units is their water resistance, and its criterion is the coefficient of water resistance. The definition of water-resistant agronomically valuable aggregates (wet sieving) shows that the amount for shelf cultivation is $27.92 \%$, ie according to the evaluation scale of DSTU 7872: 2015 Soil protection. Soil degradation. Assessment of chemical and physical soil degradation, the soil is characterized as unsatisfactory. The coefficient of water resistance was equal to 0.29 (Table 3).

Table 3. Changes in the qualitative composition of the structure of dark chestnut soil in different ways and the depth of its main cultivation (layer 0-40 cm) on average for 2016-2019

\begin{tabular}{|c|c|c|c|c|c|c|c|c|c|c|}
\hline \multicolumn{9}{|c|}{ Unit size, mm (content,\%) } & \multirow{2}{*}{$\begin{array}{l}\text { Coefficient } \\
\text { of } \\
\text { structure } \\
\text { (Ks) }\end{array}$} & \multirow{2}{*}{$\begin{array}{l}\text { Coefficient } \\
\text { of water } \\
\text { resistance } \\
(\mathrm{Kv})\end{array}$} \\
\hline$>10$ & $10-7$ & $7-5$ & $5-3$ & $3-2$ & $2-1$ & $1-0.5$ & $\begin{array}{l}0.5- \\
0.25\end{array}$ & $<0.25$ & & \\
\hline \multicolumn{11}{|c|}{ Shelf processing } \\
\hline \multirow{2}{*}{35.56} & $\underline{10.61}$ & $\underline{7.17}$ & $\underline{10.88}$ & 10.21 & $\underline{11.55}$ & $\underline{5.26}$ & $\underline{5.9}$ & $\underline{2.86}$ & \multirow{2}{*}{1.6} & \multirow{2}{*}{0.29} \\
\hline & 0.47 & 0.59 & 0.92 & 0.92 & 1.95 & 7.63 & 15.44 & 72.08 & & \\
\hline \multicolumn{11}{|c|}{ Shelfless cultivation - 1} \\
\hline \multirow{2}{*}{40.97} & $\underline{8.96}$ & $\underline{8.74}$ & $\underline{9.36}$ & $\underline{9.58}$ & $\underline{10.66}$ & $\underline{4.35}$ & 4.01 & $\underline{3.37}$ & \multirow{2}{*}{1.3} & \multirow{2}{*}{0.28} \\
\hline & 0.53 & 0.65 & 0.71 & 0.95 & 1.55 & 6.88 & 16.22 & 72.51 & & \\
\hline \multicolumn{11}{|c|}{ Shelfless cultivation - 2} \\
\hline \multirow{2}{*}{42.67} & $\underline{9.45}$ & $\underline{8.56}$ & $\underline{8.61}$ & 8.29 & $\underline{9.46}$ & $\underline{4.88}$ & $\underline{4.62}$ & $\underline{3.46}$ & \multirow{2}{*}{1.2} & \multirow{2}{*}{0.27} \\
\hline & 0.55 & 0.66 & 0.8 & 0.81 & 1.76 & 5.52 & 15.91 & 73.99 & & \\
\hline \multicolumn{11}{|c|}{ Differentiated - 1} \\
\hline \multirow{2}{*}{35.46} & $\underline{9.81}$ & 7.51 & 11.18 & 10.50 & $\underline{11.96}$ & 4.87 & $\underline{5.34}$ & $\underline{3.37}$ & \multirow{2}{*}{1.6} & \multirow{2}{*}{0.30} \\
\hline & 0.49 & 0.47 & 0.85 & 0.97 & 1.89 & 8.24 & 15.83 & 71.26 & & \\
\hline \multicolumn{11}{|c|}{ Differentiated - 2} \\
\hline בר חי & $\underline{8.54}$ & $\underline{7.85}$ & $\underline{7.97}$ & $\underline{9.06}$ & $\underline{11.92}$ & $\underline{5.01}$ & $\underline{5.40}$ & $\underline{3.53}$ & \multirow{2}{*}{1.3} & \multirow{2}{*}{0.29} \\
\hline 40.12 & 0.58 & 0.68 & 0.69 & 0.73 & 1.46 & 6.53 & 16.86 & 72.47 & & \\
\hline
\end{tabular}

In the system of long-term use of multi-depth tillage in crop rotation after chisel tillage (option 2) there is a deterioration of the structural and aggregate composition of the soil relative to the control multi-depth shelf tillage in crop rotation (option 1), it was noted the decrease in the number of 
agronomically-valuable sizes of mesoaggregates of $0.25-10 \mathrm{~mm}$ by $5.92 \%$, most valuable aggregates $1-5 \mathrm{~mm}$ in size - by $3.4 \%$, waterproof aggregates - by $0.43 \%$ and an increase in aggregates $>10 \mathrm{~mm}$ by $5.41 \%$. The coefficients of structure and water resistance decreased to 1.3 and 0.28 , respectively.

The most significant deteriorations of structural and aggregate composition in the experiment were observed for the implementation of disk shallow tillage (option 3) and for the system of longterm use of single-depth shallow tillage in crop rotation. There is a destruction and reduction of the number of agronomically-valuable mesoaggregates of $0.25-10 \mathrm{~mm}$ by $7.71 \%$, the most valuableaggregates of $1-5 \mathrm{~mm}$ - by $6.28 \%$. The sum of aggregates $>10 \mathrm{~mm}$ in this option was the largest in the experiment and reached $60.68 \%$ and there is a significant increase in soil dispersion (sum of aggregates $<0.25 \mathrm{~mm}$ ) by $0.6 \%$, which is $3.46 \%$ compared with the data obtained from the control (option 1). Under such conditions, the structural factor decreases to 1.2. Water-resistant structure, which determines the structure of soils and its stability over time and resists the destructive action of water, decreased (the number of water-resistant units) - by $1.91 \%$, which reduced the coefficient of water resistance - to 0.27 , which is the lowest value of this indicator in the experiment. According to the scale of assessment of structural and aggregate composition, the soil in this variant (option 3) is characterized as unsatisfactory.

According to the results of research, there is a deterioration in the structural composition of irrigated soils, which occurs due to the destruction and reduction of agronomically valuable mesoaggregates of $0.25-10 \mathrm{~mm}$ and a sharp increase in aggregates over $10 \mathrm{~mm}$. Partial replacement of absorbing calcium in the colloidal soil complex by absorbing magnesium and sodium causes the transition of a significant part of colloids to the state of reverse coagulation, which in turn leads to the destruction of the structure.

With long-term use of differentiated tillage with one split for crop rotation (option 4), the number of agronomically valuable mesoaggregates is observed at the control level, size $0.25-10 \mathrm{~mm}-61.17 \%$, which is less than only $0.41 \%$; and the most valuable units with a size of $1-5 \mathrm{~mm}-1 \%$ more. Soil brittleness (sum of units $>10 \mathrm{~mm}$ ) is also at the level of option $1-35.46 \%$. The obtained data show that the scale of assessment of the structural and aggregate condition of the soil is characterized as satisfactory. Determination of water resistance of units (wet sieving) shows that the sum of units larger than $0.25 \mathrm{~mm}$ for systems of differentiated tillage (option 4) increased relative to control by $0.82 \%$, which increased the coefficient of water resistance to 0.30 , with the coefficient of structure at the level of shelf processing (option 1) - being 1.6.

After differentiated tillage in the system with one plow per rotation (option 5) there is a deterioration of the structural and aggregate composition of the soil relative to the control of different depth tillage in crop rotation. Namely there was a decrease in agronomically-valuable mesoaggregates of $0.25-10 \mathrm{~mm}$ by $5.83 \%$; the most valuable units with a size of $1-5 \mathrm{~mm}$ - by $3.69 \%$. Determination of water resistance of aggregates (wet sieving) shows that the sum of units larger than $0.25 \mathrm{~mm}$ for differentiated-2 systems (option 5 ) decreased by $0.39 \%$. Under such conditions, the coefficients of structure and water resistance are 1.3 and 0.29 , respectively, which is better than options 2 and 3 .

The density of the soil structure characterizes the porosity and structure, water permeability, aeration and directly affects the water, air, thermal regimes and biological activity of the soil. The 
density of the structure is characterized by greater dynamism, which is due to the duration of irrigation, humidity and fertilizer system.

For corn, the optimal density of the arable soil layer is $1.1-1.3 \mathrm{~g} / \mathrm{cm}^{3}$. The most optimal level of this indicator is provided by carrying out various depth system of the main tillage. Thus, the density of the soil layer at 0-40 during the period of seedlings in the variants of the experiment ranged from 1.24 to $1.31 \mathrm{~g} / \mathrm{cm}^{3}$ (Table 4).

Table 4. Density of formation and water permeability of the soil layer $0-40 \mathrm{~cm}$ depending on the method and depth of the main tillage at the beginning and end of the corn growing season on average for 2016-2019

\begin{tabular}{|c|c|c|c|c|c|}
\hline \multirow{2}{*}{ 을 $\frac{\text { 음 }}{\text { 을 }}$} & \multirow[b]{2}{*}{$\begin{array}{l}\text { Basic tillage } \\
\text { system }\end{array}$} & \multicolumn{2}{|c|}{$\begin{array}{c}\text { The beginning of the } \\
\text { growing season }\end{array}$} & \multicolumn{2}{|c|}{$\begin{array}{l}\text { The end of the growing } \\
\text { season }\end{array}$} \\
\hline & & $\begin{array}{l}\text { Density, } \\
\mathrm{g} / \mathrm{cm}^{3}\end{array}$ & $\begin{array}{c}\text { Water } \\
\text { permeability, } \\
\mathrm{mm} / \mathrm{min}\end{array}$ & $\begin{array}{l}\text { Denseness, } \\
\mathrm{g} / \mathrm{cm}^{3}\end{array}$ & $\begin{array}{c}\text { Water } \\
\text { permeability, } \\
\mathrm{mm} / \mathrm{min}\end{array}$ \\
\hline 1 & Shelf processing & 1.24 & 4.8 & 1.26 & 4.2 \\
\hline 2 & Shelfless - 1 & 1.27 & 4.1 & 1.29 & 3.6 \\
\hline 3 & Shelfless - 2 & 1.31 & 3.5 & 1.33 & 3.0 \\
\hline 4 & Differentiated-1 & 1.26 & 4.3 & 1.28 & 3.5 \\
\hline 5 & Differentiated-2 & 1.27 & 4.6 & 1.29 & 3.8 \\
\hline
\end{tabular}

The top layer of soil $0-10 \mathrm{~cm}$ was the most loose. Intensive compaction process takes place in the variants of cultivation without rotation of the slice (options 2 and 3), reaching the maximum values in the variant of disk cultivation by $12-14 \mathrm{~cm}$ in the system of shelfless shallow single-depth main tillage in crop rotation.

Before harvesting, the density of addition increased to $1.26-1.33 \mathrm{~g} / \mathrm{cm}^{3}$. Characteristic of all variants is that the increased density of the soil layer $0-40 \mathrm{~cm}$ was formed mainly due to the compaction of the layers $10-20$ and $20-30 \mathrm{~cm}$, especially at the end of the growing season - the soil layer $30-40 \mathrm{~cm}$.

In direct dependence on the density of the arable layer is its porosity. Thus, when determining at the beginning of the growing season the porosity of the soil layer $0-40 \mathrm{~cm}$ ranged from 49.8 to $52.4 \%$. There was no significant difference between the options of basic tillage in the determination, both at the beginning of the growing season and before harvest. The lowest indicators of total porosity corresponded to the variant of disk tillage by $12-14 \mathrm{~cm}$ carried out against the background of long-term use of the system of shallow single-depth shelfless loosening in crop rotation during rotation and amounted to 49.8 and $49.0 \%$.

Soil porosity during the corn harvest period decreased in all variants. The influence of experimental variants on this indicator had a similar tendency as in the germination period. The highest rate of porosity before harvest was observed for shelf different depth of main tillage and amounted to $51.72 \%$. 
One of the most important water-physical properties of the soil, associated with the density of composition and porosity, is the ability of the soil to absorb and filter through itself the water that is supplied during vegetation irrigation and comes with precipitation. In our experiments during the period of maize germination there is a decrease in water permeability by $1.3 \mathrm{~mm} / \mathrm{min}$ in the variant of differentiated- 1 and 2 shelfless single-depth main tillage in crop rotation (option 3). Close to the control were the indicators for the differentiated-2 system and were $4.6 \mathrm{~mm} / \mathrm{min}$, ie were within error.

The decrease in pre-harvest density led to a decrease in water permeability by shallow disk tillage by $28.6 \%$ compared to the control. Water permeability in the variant of disk tillage to a depth of $8-10 \mathrm{~cm}$ in the system of differentiated-2 main tillage (option 5) was $3.8 \mathrm{~mm} / \mathrm{min}$.

Correlation-regression analysis of the obtained indicators allowed to obtain the equation of the dependence of water permeability on the density of soil composition: $y=56,025 x^{2}-161,09 x+118,16$, $\left(R^{2}=0,8481\right)$, which confirms the close relationship between these indicators and indicate that the regulation of the density of composition can significantly affect the water permeability of the soil.

That is, the reduction of soil composition density due to chisel tillage to a depth of $12-14 \mathrm{~cm}$ with one slit per rotation by $38-40 \mathrm{~cm}$ in the system of differentiated tillage (option 4) contributes to a stable increase in soil permeability.

Experimental data for 2016-2019 show that at the beginning of the winter wheat vegetation the content of exchange cations of $0-40 \mathrm{~cm}$ of the soil layer did not differ significantly in all the studied variants. In the plowing variants in the system of long-term application of different depth tillage and in the system of differentiated crop rotation (variants 1 and 4) against the background of fertilizer application, the content of absorbed calcium was insignificantly higher compared to other studied variants and averaged $12.5 \mathrm{meq} / 100 \mathrm{~g}$ (68\% of the amount of absorbed cations) at 11.6 $12.0 \mathrm{mEq} / 100 \mathrm{~g}$ in other variants (65-66\% of the amount of absorbed cations). Differentiation of the absorbed sodium content was observed in the range of $0.59-0.71 \mathrm{mEq} / 100 \mathrm{~g}$ of soil (3.4-4.0\% of the amount of absorbed cations), which indicates a weak degree of irrigation salinity according to this indicator. The content of absorbed sodium at the level of $0.71 \mathrm{mEq} / 100 \mathrm{~g}$ of soil (4.0\%) of the amount of absorbed cations was observed for disk tillage to a depth of $12-14 \mathrm{~cm}$ in the system of shallow single-depth tillage in crop rotation (option 3 ) without fertilizers. The content of absorbed magnesium averaged 5.2-5.5 mEq/100 g of soil (29-31\%).

Analysis of the data on the content of exchangeable cations in the $0-40 \mathrm{~cm}$ layer of soil at the end of the growing season shows that in all studied variants there is a slight increase in absorbed sodium (up to $1 \%$ ), but this does not affect the degree of irrigation salinity and corresponds to a weak level.

Thus, the studied types of tillage do not show a significant impact on the physico-chemical process of desalination of the soil during the study period. Some decrease in the content of absorbed sodium in the composition of the soil absorption complex at the beginning of the growing season is probably due to the difference in agrophysical properties (Table 5). 
Table 5. Dynamics of exchange cations in dark chestnut soil by different methods of basic cultivation on average for 2016-2019 of the winter wheat growing season

\begin{tabular}{|c|c|c|c|c|c|c|c|c|c|}
\hline \multirow{3}{*}{$\begin{array}{l}\frac{\text { ô }}{20} \\
\frac{0}{0} \\
\frac{01}{2}\end{array}$} & \multirow{3}{*}{$\begin{array}{l}\text { Basic tillage system } \\
\text { (Factor A) }\end{array}$} & \multicolumn{4}{|c|}{ Beginning of growing season } & \multicolumn{4}{|c|}{ End of the growing season } \\
\hline & & \multicolumn{3}{|c|}{$\begin{array}{c}\text { Content of } \\
\text { exchangeable cations, } \\
\mathrm{mEq} / 100 \mathrm{~g} \text { of soil }\end{array}$} & \multirow{2}{*}{$\begin{array}{c}\text { The } \\
\text { amount of } \\
\text { exchangeable } \\
\text { cations, } \\
\mathrm{mEq} / 100 \mathrm{~g} \\
\text { of soil }\end{array}$} & \multicolumn{3}{|c|}{$\begin{array}{c}\text { Content of } \\
\text { exchangeable cations, } \\
\mathrm{mEq} / 100 \mathrm{~g} \text { of soil }\end{array}$} & \multirow[t]{2}{*}{$\begin{array}{c}\text { The amount of } \\
\text { exchangeable } \\
\text { cations, mEq/100 } \\
\text { g of soil }\end{array}$} \\
\hline & & $\mathrm{Ca}^{2+}$ & $\mathrm{Mg}^{2+}$ & $\mathrm{Na}^{+}$ & & $\mathrm{Ca}^{2+}$ & $\mathrm{Mg}^{2+}$ & $\mathrm{Na}^{+}$ & \\
\hline \multicolumn{10}{|c|}{ Power supply background (Factor B) } \\
\hline \multicolumn{10}{|c|}{ No fertilizers } \\
\hline 1 & Shelf processing & 12 & 5.4 & 0.63 & 18.0 & 12 & 5.6 & 0.79 & 18.4 \\
\hline 2 & Shelfless - 1 & 12 & 5.4 & 0.68 & 18.1 & 11.8 & 5.6 & 0.83 & 18.2 \\
\hline 3 & Shelfless - 2 & 11.6 & 5.5 & 0.71 & 17.8 & 11.6 & 5.6 & 0.85 & 18.1 \\
\hline 4 & Differentiated-1 & 12 & 5.4 & 0.63 & 18.0 & 12 & 5.6 & 0.78 & 18.4 \\
\hline 5 & Differentiated-2 & 12 & 5.4 & 0.67 & 18.1 & 11.9 & 5.6 & 0.81 & 18.3 \\
\hline \multicolumn{10}{|c|}{$\mathrm{N}_{82,5} \mathrm{P}_{45}{ }^{*}$} \\
\hline 1 & Shelf processing & 12.2 & 5.3 & 0.62 & 18.1 & 12.2 & 5.5 & 0.75 & 18.5 \\
\hline 2 & Shelfless - 1 & 12.1 & 5.4 & 0.66 & 18.2 & 12.1 & 5.6 & 0.79 & 18.5 \\
\hline 3 & Shelfless - 2 & 11.8 & 5.4 & 0.69 & 17.9 & 11.8 & 5.6 & 0.84 & 18.2 \\
\hline 4 & Differentiated-1 & 12.3 & 5.3 & 0.61 & 18.2 & 12.3 & 5.5 & 0.75 & 18.6 \\
\hline 5 & Differentiated-2 & 12.2 & 5.4 & 0.65 & 18.3 & 12.2 & 5.6 & 0.77 & 18.6 \\
\hline \multicolumn{10}{|c|}{$\mathrm{N}_{120} \mathrm{P}_{52,5}{ }^{*}$} \\
\hline 1 & Shelf processing & 12.5 & 5.2 & 0.6 & 18.3 & 12.4 & 5.5 & 0.73 & 18.6 \\
\hline 2 & Shelfless - 1 & 12.2 & 5.3 & 0.65 & 18.2 & 12.2 & 5.6 & 0.77 & 18.6 \\
\hline 3 & Shelfless - 2 & 12 & 5.4 & 0.67 & 18.1 & 11.9 & 5.6 & 0.82 & 18.3 \\
\hline 4 & Differentiated-1 & 12.5 & 5.2 & 0.59 & 18.3 & 12.5 & 5.5 & 0.72 & 18.7 \\
\hline 5 & Differentiated-2 & 12.3 & 5.2 & 0.64 & 18.1 & 12.3 & 5.5 & 0.76 & 18.6 \\
\hline \multicolumn{2}{|c|}{$\mathrm{LSD}_{05^{\prime}} \mathrm{mEq} / 100 \mathrm{~g}$ of soil: } & \multicolumn{4}{|c|}{$\begin{aligned} A & =0.03, A=0.02, A=0.005 \\
B & =0.02, B=0.02, B=0.005\end{aligned}$} & \multicolumn{4}{|c|}{$\begin{aligned} A & =0.03, A=0.02, A=0.005 \\
B & =0.03, B=0.02, B=0.006\end{aligned}$} \\
\hline
\end{tabular}

Note: ${ }^{*}$ - the average doses of fertilizers according to the studied agricultural products are indicated.

Analysis of the aqueous extract of dark chestnut soil on the studied variants showed that at the beginning of the soybean vegetation on average in 2016-2019, the content of water-soluble salts in the $0-40 \mathrm{~cm}$ layer was in the range of $0.74-0.86 \%$ (Table 6). The amount of toxic salts (0.046-0.057\%) is not saline soil. The largest amount of toxic salts was observed in the variants without fertilizers $0.048-0.057 \%$, the application of fertilizers slightly reduced their content to $0.046-0.056 \%$. The ratio of calcium cations to sodium in the soil solution varies in the layer of $0-40 \mathrm{~cm}$ in the range from 0.73 to 1.03 units. 
Table 6. Ion-salt composition of water extract in dark chestnut soil with different methods of basic cultivation and doses of fertilizers at the beginning of the growing season on average for 2016-2019

\begin{tabular}{|c|c|c|c|c|c|c|c|c|c|c|c|c|}
\hline \multirow{2}{*}{$\begin{array}{l}\widehat{\frac{0}{0}} \\
\frac{0}{0} \\
\frac{0}{2}\end{array}$} & \multirow{2}{*}{$\begin{array}{l}\text { Soil } \\
\text { layer }\end{array}$} & \multicolumn{7}{|c|}{ Ion content, $\mathrm{mEq} / 100 \mathrm{~g}$ of soil } & \multicolumn{2}{|c|}{$\begin{array}{l}\text { The amount of } \\
\text { salts, } \%\end{array}$} & \multirow{2}{*}{$\begin{array}{l}\mathrm{Ca}^{2+} \mathrm{I} \\
\mathrm{Na}^{+}\end{array}$} & \multirow{2}{*}{$\mathrm{pH}$} \\
\hline & & $\mathrm{CO}_{3}^{-}$ & $\mathrm{HCO}_{3}^{-}$ & $\mathrm{Cl}^{-}$ & $\mathrm{SO}_{4}^{2-}$ & $\mathrm{Ca}^{2+}$ & $\mathrm{Mg}^{2+}$ & $\mathrm{Na}^{+}$ & general & toxic & & \\
\hline \multicolumn{13}{|c|}{ No fertilizers } \\
\hline 1 & $0-40$ & 0.00 & 0.36 & 0.26 & 0.53 & 0.40 & 0.30 & 0.45 & 0.079 & 0.050 & 0.89 & 7.4 \\
\hline 2 & $0-40$ & 0.00 & 0.38 & 0.26 & 0.59 & 0.40 & 0.30 & 0.53 & 0.085 & 0.055 & 0.75 & 7.5 \\
\hline 3 & $0-40$ & 0.00 & 0.38 & 0.25 & 0.62 & 0.40 & 0.30 & 0.55 & 0.086 & 0.057 & 0.73 & 7.6 \\
\hline 4 & $0-40$ & 0.00 & 0.35 & 0.25 & 0.52 & 0.40 & 0.30 & 0.42 & 0.076 & 0.048 & 0.95 & 7.4 \\
\hline 5 & $0-40$ & 0.00 & 0.36 & 0.25 & 0.62 & 0.40 & 0.20 & 0.63 & 0.085 & 0.055 & 0.63 & 7.5 \\
\hline \multicolumn{13}{|c|}{ Power supply background $1-\mathrm{N}_{82,5} \mathrm{P}_{45}{ }^{*}$} \\
\hline 1 & $0-40$ & 0.00 & 0.35 & 0.25 & 0.54 & 0.40 & 0.30 & 0.44 & 0.078 & 0.049 & 0.91 & 7.3 \\
\hline 2 & $0-40$ & 0.00 & 0.35 & 0.26 & 0.60 & 0.40 & 0.30 & 0.51 & 0.083 & 0.054 & 0.78 & 7.5 \\
\hline 3 & $0-40$ & 0.00 & 0.36 & 0.26 & 0.62 & 0.40 & 0.30 & 0.54 & 0.085 & 0.056 & 0.74 & 7.5 \\
\hline 4 & $0-40$ & 0.00 & 0.33 & 0.24 & 0.52 & 0.40 & 0.30 & 0.39 & 0.074 & 0.046 & 1.03 & 7.3 \\
\hline 5 & $0-40$ & 0.00 & 0.38 & 0.26 & 0.52 & 0.40 & 0.20 & 0.56 & 0.081 & 0.051 & 0.71 & 7.5 \\
\hline \multicolumn{13}{|c|}{ Power supply background $2-\mathrm{N}_{120} P_{52,5}{ }^{*}$} \\
\hline 1 & $0-40$ & 0.00 & 0.34 & 0.25 & 0.53 & 0.40 & 0.30 & 0.42 & 0.076 & 0.048 & 0.95 & 7.3 \\
\hline 2 & $0-40$ & 0.00 & 0.35 & 0.26 & 0.57 & 0.40 & 0.30 & 0.48 & 0.081 & 0.052 & 0.83 & 7.4 \\
\hline 3 & $0-40$ & 0.00 & 0.36 & 0.25 & 0.61 & 0.40 & 0.30 & 0.52 & 0.084 & 0.055 & 0.77 & 7.5 \\
\hline 4 & $0-40$ & 0.00 & 0.34 & 0.25 & 0.50 & 0.40 & 0.30 & 0.39 & 0.074 & 0.046 & 1.03 & 7.3 \\
\hline 5 & $0-40$ & 0.00 & 0.38 & 0.25 & 0.52 & 0.40 & 0.20 & 0.55 & 0.080 & 0.050 & 0.73 & 7.5 \\
\hline
\end{tabular}

Note: * - the average doses of fertilizers according to the studied agricultural products are indicated.

Type of salinization of soil solution by ionic composition chloride-sulphate calcium-sodium. However, in the system of differentiated tillage with one slit for crop rotation on the background of fertilizer application, the type of salinization of the soil solution of sodium chloride chloridesulphate is noted (NI Bazylevych, El Pankova). Studies have shown that irrigation of the Ingulets irrigation system with an unfavorable ratio of monovalent and divalent cations leads to changes in the ionic-salt composition of the aqueous extract of the soil.

After harvesting, the content of water-soluble salts in the layer of $0-40 \mathrm{~cm}$ of soil increased in all variants of the experiment to $0.075-0.085 \%$. The increase in salts was mainly due to the increase in $\mathrm{SO}_{4}^{2-}$ and $\mathrm{Cl}^{-}$ions among the anions and $\mathrm{Na}^{+}$among the cations (Table 7). The content of toxic salts in the $0-40 \mathrm{~cm}$ layer in the soil of all variants of the experiment also increased by $12-15$ relative percent. However, their lowest content is observed in the system of differentiated cultivation of crop rotation (option 4) on the background of making $\mathrm{N}_{180} 0.051 \%$ in the layer $0-40 \mathrm{~cm}$. The ratio of calcium cations to sodium in the soil solution ranges from 0.44 to 0.85 units, which indicates the 

Zbornik Veleučilišta u Rijeci, Vol. 9 (2021), No. 1, pp. 423-439

development of the process of secondary salinization. Transformation of the ionic composition of the aqueous extract led to a change in the chemistry of salinity, it became the ionic composition of calcium chloride-sulfate in all variants, regardless of the factors studied. Metabolic processes in the soil-absorbing complex caused an increase in the number of sodium cations in the soil solution. Their highest content of $0.65-0.68 \mathrm{mEq} / 100 \mathrm{~g}$ of soil was observed in the variants of disk cultivation to a depth of $12-14 \mathrm{~cm}$ in the system of shallow single-depth tillage in crop rotation (option 3 ). Also during this treatment, in the variant without mineral fertilizers, the highest amount of sodium was observed in the experiment of $0.68 \mathrm{mEq} / 100 \mathrm{~g}$ in a layer of $0-40 \mathrm{~cm}$. It should be noted that the highest ratio of water-soluble calcium to sodium in the ratio -0.85 is observed in the variants with fertilizers on the background of the system of long-term use of different depth shelf and differentiated tillage in crop rotation (option 4).

Table 7. Ion-salt composition of water extract in dark chestnut soil with different methods of basic cultivation and doses of fertilizers at the end of the growing season on average for 2016-2019

\begin{tabular}{|c|c|c|c|c|c|c|c|c|c|c|c|c|}
\hline \multirow[t]{2}{*}{ № } & \multirow{2}{*}{$\begin{array}{c}\text { Layer } \\
\text { soil, } \\
\mathrm{cm}\end{array}$} & \multicolumn{7}{|c|}{ Ion content, mEq/100 g of soil } & \multicolumn{2}{|c|}{$\begin{array}{c}\text { The amount of } \\
\text { salts, } \%\end{array}$} & \multirow{2}{*}{$\begin{array}{l}\mathrm{Ca}^{2+} / \\
\mathrm{Na}^{+}\end{array}$} & \multirow[t]{2}{*}{$\mathrm{pH}$} \\
\hline & & $\mathrm{CO}_{3}^{-}$ & $\mathrm{HCO}_{3}^{-}$ & $\mathrm{Cl}^{-}$ & $\mathrm{SO}_{4}^{2-}$ & $\mathrm{Ca}^{2+}$ & $\mathrm{Mg}^{2+}$ & $\mathrm{Na}^{+}$ & general & toxic & & \\
\hline \multicolumn{13}{|c|}{ No fertilizers } \\
\hline 1 & $0-40$ & 0.00 & 0.24 & 0.36 & 0.61 & 0.40 & 0.30 & 0.51 & 0.080 & 0.054 & 0.78 & 7.5 \\
\hline 2 & $0-40$ & 0.00 & 0.25 & 0.38 & 0.61 & 0.30 & 0.30 & 0.64 & 0.082 & 0.063 & 0.47 & 7.7 \\
\hline 3 & $0-40$ & 0.00 & 0.25 & 0.38 & 0.65 & 0.30 & 0.30 & 0.68 & 0.085 & 0.065 & 0.44 & 7.7 \\
\hline 4 & $0-40$ & 0.00 & 0.24 & 0.35 & 0.62 & 0.40 & 0.30 & 0.51 & 0.080 & 0.054 & 0.78 & 7.5 \\
\hline 5 & $0-40$ & 0.00 & 0.28 & 0.39 & 0.50 & 0.30 & 0.30 & 0.57 & 0.078 & 0.058 & 0.53 & 7.6 \\
\hline \multicolumn{13}{|c|}{ Power supply background $1-\mathrm{N}_{82,5} \mathrm{P}_{45}{ }^{*}$} \\
\hline 1 & $0-40$ & 0.00 & 0.24 & 0.36 & 0.60 & 0.40 & 0.30 & 0.50 & 0.079 & 0.053 & 0.80 & 7.5 \\
\hline 2 & $0-40$ & 0.00 & 0.26 & 0.37 & 0.58 & 0.30 & 0.30 & 0.61 & 0.080 & 0.061 & 0.49 & 7.6 \\
\hline 3 & $0-40$ & 0.00 & 0.26 & 0.37 & 0.62 & 0.30 & 0.30 & 0.65 & 0.083 & 0.063 & 0.46 & 7.7 \\
\hline 4 & $0-40$ & 0.00 & 0.24 & 0.35 & 0.60 & 0.40 & 0.30 & 0.49 & 0.079 & 0.053 & 0.82 & 7.4 \\
\hline 5 & $0-40$ & 0.00 & 0.28 & 0.39 & 0.51 & 0.30 & 0.30 & 0.58 & 0.078 & 0.059 & 0.52 & 7.6 \\
\hline \multicolumn{13}{|c|}{ Power supply background $2-\mathrm{N}_{120} \mathrm{P}_{52,5}{ }^{*}$} \\
\hline 1 & $0-40$ & 0.00 & 0.24 & 0.36 & 0.60 & 0.40 & 0.30 & 0.50 & 0.079 & 0.053 & 0.80 & 7.4 \\
\hline 2 & $0-40$ & 0.00 & 0.25 & 0.37 & 0.57 & 0.30 & 0.30 & 0.59 & 0.079 & 0.059 & 0.51 & 7.6 \\
\hline 3 & $0-40$ & 0.00 & 0.25 & 0.37 & 0.63 & 0.30 & 0.30 & 0.65 & 0.083 & 0.063 & 0.46 & 7.7 \\
\hline 4 & $0-40$ & 0.00 & 0.24 & 0.35 & 0.58 & 0.40 & 0.30 & 0.47 & 0.077 & 0.051 & 0.85 & 7.4 \\
\hline 5 & $0-40$ & 0.00 & 0.26 & 0.38 & 0.50 & 0.30 & 0.30 & 0.54 & 0.075 & 0.056 & 0.56 & 7.5 \\
\hline
\end{tabular}

Note: * - the average doses of fertilizers according to the studied agricultural products are indicated.

Analysis of crop yield data on average for 2016-2019 shows that compared to plowing to a depth of $20-22 \mathrm{~cm}$ in the system of long-term use of shallow tillage in crop rotation (option 1), the increase in corn yield was only for disk tillage to depth $8-10 \mathrm{~cm}$ in a system of differentiated cultivation 
(option 4) and amounted to an average of factor a («way of cultivation») 3.0\%, the level of yield depending on the dose of fertilizers 12,31-15,49 $\mathrm{t} / \mathrm{ha}$.

Disc tillage to a depth of $12-14 \mathrm{~cm}$ in the system of shallow single-depth tillage in crop rotation (option 3) led to a decrease in yield by $33.7 \%$, and without applying fertilizer to the lowest yield in the experiment $3.11 \mathrm{t} / \mathrm{ha}$. Fertilization with doses of $\mathrm{N}_{120}$ and $\mathrm{N}_{180}$ increased the yield on average by factor $B$ ("dose of fertilizer") by 166.4 and $233.3 \%$. When applying $\mathrm{N}_{90}$ sorghum, the yield was increased by $146.5 \%$, the increase in the dose of mineral fertilizers contributed to a lower yield germination compared to other crops in the experiment, which on the background of $\mathrm{N}_{120}$ was $175.9 \%$, respectively (Table 8 ).

The influence of the method of tillage on the yield of sorghum is a similar trend with other crops. Carrying out chisel tillage to a depth of $12-14 \mathrm{~cm}$ with a gap of $38-40 \mathrm{~cm}$ in the system of differentiated tillage (option 4) compared with plowing to a depth of $23-25 \mathrm{~cm}$ in the system of long-term application of shallow shelf tillage in crop rotation (option 1 ) increased yield on average by factor A («method of tillage») 2.9\%. Replacement of deep tillage with disc tillage to a depth of $12-14 \mathrm{~cm}$ in the system of long-term use of single-depth shallow tillage in crop rotation (option 3 ) led to a decrease in yield by $32.1 \%$, in other options - by $5.6-10.9 \%$. The highest sorghum yield in the experiment was obtained in option 4 with the application of mineral fertilizers at a dose of $\mathrm{N}_{120^{\prime}}$ which amounted to $8.72 \mathrm{t} / \mathrm{ha}$.

Table 8. Crop yields on average in 2016-2019 under the influence of various elements of agricultural cultivation technology

\begin{tabular}{|c|c|c|c|c|c|}
\hline \multirow{2}{*}{$\begin{array}{c}\text { № } \\
\text { (option) }\end{array}$} & \multirow{2}{*}{ Basic tillage system (Factor A) } & \multicolumn{4}{|c|}{ Yield, t/ha } \\
\hline & & corn & soy & winter wheat & sorghum \\
\hline \multicolumn{6}{|c|}{ Power background (Factor B) } \\
\hline \multicolumn{6}{|c|}{ No fertilizers } \\
\hline 1 & Shelf processing & 3.63 & 2.81 & 3.11 & 2.82 \\
\hline 2 & Shelfless-1 & 3.96 & 2.46 & 3.00 & 2.50 \\
\hline 3 & Shelfless-2 & 3.11 & 2.07 & 2.81 & 2.14 \\
\hline 4 & Differentiated-1 & 4.77 & 2.77 & 3.17 & 3.35 \\
\hline 5 & Differentiated-2 & 4.32 & 2.27 & 2.89 & 2.32 \\
\hline \multicolumn{6}{|c|}{ Power background 1} \\
\hline & & $\mathrm{N}_{120}$ & $\mathrm{~N}_{30} \mathrm{P}_{60}$ & $\mathrm{~N}_{90} \mathrm{P}_{60}$ & $\mathrm{~N}_{90} \mathrm{P}_{60}$ \\
\hline 1 & Shelf processing & 11.98 & 3.59 & 5.97 & 7.54 \\
\hline 2 & Shelfless-1 & 11.05 & 3.41 & 5.91 & 7.15 \\
\hline 3 & Shelfless-2 & 7.97 & 2.83 & 5.89 & 4.96 \\
\hline 4 & Differentiated-1 & 12.31 & 3.64 & 6.05 & 6,51 \\
\hline 5 & Differentiated-2 & 11.91 & 3.22 & 5.92 & 6.83 \\
\hline \multicolumn{6}{|c|}{ Power background 2} \\
\hline & & $\mathrm{N}_{180}$ & $\mathrm{~N}_{60} \mathrm{P}_{60}$ & $\mathrm{~N}_{120} \mathrm{P}_{60}$ & $\mathrm{~N}_{120} \mathrm{P}_{60}$ \\
\hline 1 & Shelf processing & 15.06 & 4.27 & 6.89 & 7.70 \\
\hline
\end{tabular}


I. Bidnyna, O. Shkoda, A. Tomnytskyi, V. Borovik, V. Sharii: Patterns of soil processes on dark chestnut... Zbornik Veleučilišta u Rijeci, Vol. 9 (2021), No. 1, pp. 423-439

\begin{tabular}{|c|c|c|c|c|c|}
\hline 2 & Shelfless-1 & 14.43 & 3.92 & 6.82 & 7.40 \\
\hline 3 & Shelfless-2 & 9.87 & 3.15 & 6.74 & 5.17 \\
\hline 4 & Differentiated-1 & 15.49 & 4.01 & 7.07 & 8.72 \\
\hline 5 & Differentiated-2 & 14.24 & 3.49 & 6.77 & 6.94 \\
\hline
\end{tabular}

In the experiment with winter wheat, fertilizer application increased crop yields on average by factor B («fertilizer dose») by 96.5 and $128.9 \%$, respectively. The influence of tillage methods on the yield of winter wheat was less effective. When carrying out disk tillage to a depth of $8-10 \mathrm{~cm}$ in the system of differentiated tillage with one slit for crop rotation (option 4) there was an increase in winter wheat yield on average by factor $A$ ( «tillage method») by $2 \%$, while for others options $(2,3$, 5 ), the shortage of harvest compared to plowing to a depth of $14-16 \mathrm{~cm}$ in the system of long-term use of different depth tillage in crop rotation (option 1) ranged from 1.5 to $5.2 \%$.

Yields of soybeans for plowing to a depth of $25-27 \mathrm{~cm}$ (option 1) and tillage to a depth of 14$16 \mathrm{~cm}$ (option 4) on fertilized backgrounds was the highest and ranged depending on the doses of fertilizers in the range of 3.59-4.27 t/ha and 3.64-4.01 t/ha, respectively. With the reduction of tillage depth (option 3), the yield decreased on average by factor A («tillage method») by $24.6 \%$. compared to control. When fertilizers were applied at doses of $\mathrm{N}_{30} \mathrm{P}_{60}$ and $\mathrm{N}_{60} \mathrm{P}_{60}$, theyield increased on average by factor B ("fertilizer dose") by 34.8 and $52.2 \%$, respectively.

Thus, the best conditions for crop yields in the experiment were created with a differentiated tillage system with one slot for crop rotation (option 4), and with the introduction of increased doses of fertilizers, which per 1 ha of crop rotation area provided the highest productivity for corn $15.49 \mathrm{t} /$ ha, sorghum -8.72 , winter wheat -7.07 , and only for soybeans the best conditions this year were created by the option $1-4.27 \mathrm{t} / \mathrm{ha}$.

To assess the economic and energy efficiency of agricultural cultivation techniques, production costs were calculated according to the norms and prices in force within the production boundaries of the Steppe zone of Ukraine (Table 9).

Table 9. Assessment of energy and economic efficiency of growing crops under the influence of various elements of technology on average for 2016-2019, t/ha

\begin{tabular}{|c|c|c|c|c|c|c|c|c|c|}
\hline \multirow[t]{2}{*}{ № } & \multicolumn{3}{|c|}{ Profitability level,\% } & \multicolumn{3}{|c|}{$\begin{array}{l}\text { Gross energy output, } \\
\text { GJ }\end{array}$} & \multicolumn{3}{|c|}{ Energy efficiency ratio } \\
\hline & $\begin{array}{l}\text { without } \\
\text { fertilizers }\end{array}$ & $\mathrm{N}_{82.5} \mathrm{P}_{45^{*}}$ & $\mathrm{~N}_{120} \mathrm{P}_{52.5}{ }^{*}$ & $\begin{array}{l}\text { without } \\
\text { fertilizers }\end{array}$ & $\mathrm{N}_{82.5} \mathrm{P}_{45^{*}}$ & $\begin{array}{l}\mathrm{N}_{120} \\
\mathrm{P}_{52.5}{ }^{*}\end{array}$ & $\begin{array}{l}\text { without } \\
\text { fertilizers }\end{array}$ & $\mathrm{N}_{82.5} \mathrm{P}_{45^{*}}$ & $\mathrm{~N}_{120} \mathrm{P}_{52.5}{ }^{*}$ \\
\hline 1 & 59 & 160 & 182 & 64.4 & 140.0 & 163.4 & 1.7 & 3.6 & 4.1 \\
\hline 2 & 44 & 147 & 171 & 57.7 & 132.4 & 156.3 & 1.6 & 3.5 & 4.1 \\
\hline 3 & 33 & 89 & 103 & 48.8 & 102.6 & 119.7 & 1.4 & 2.8 & 3.2 \\
\hline 4 & 73 & 189 & 199 & 68.0 & 152.6 & 157.2 & 1.9 & 4.1 & 4.1 \\
\hline 5 & 41 & 152 & 167 & 56.5 & 134.3 & 151.6 & 1.5 & 3.6 & 4.0 \\
\hline
\end{tabular}

Note: * - the average doses of fertilizers according to the studied agricultural products are indicated. 
The highest level of profitability from 1 ha of crop rotation area was obtained for the average feeding background $2\left(\mathrm{~N}_{120} \mathrm{P}_{52.5}\right)$ for differentiated tillage (option 4) - 199\%, while for other tillage systems and fertilizer doses it decreased to $33-189 \%$.

The lowest level of profitability was observed for disk tillage in the system of shallow single-depth tillage in crop rotation (option 3) on an unfertilized background - 33\%. Analyzing long-term data, it was found that per 1 ha of crop rotation area chisel tillage to a depth of $12-14 \mathrm{~cm}$ with one slit per rotation of $38-40 \mathrm{~cm}$ in the system of differentiated tillage (option 4) is the most cost-effective.

It was determined that the yield of gross energy of crops per 1 ha of crop rotation area, depending on the methods of basic tillage in the unfertilized version and against the background of $\mathrm{N}_{82,5} \mathrm{P}_{45}$ was the highest at chisel tillage to a depth of $12-14 \mathrm{~cm}$ system of differentiated tillage (option 4) and amounted to 68.0 and $152.6 \mathrm{G}$ J/ha, and for $\mathrm{N}_{120} \mathrm{P}_{52.5}$ was the highest for long-term application of shallow tillage (option 1) - $163.4 \mathrm{G}$ //ha, where the gross energy in the system of differentiated tillage (option 4) were slightly lower - 157.2 GJ/ha (Table 10). In the variants using different depth troughless (option 2) and differentiated-2 (option 5) main tillage, it ranged from 132.4-156.3 and 134.3-151.6 GJ/ha, depending on the feeding background. In the variant of shelf-free shallow tillage, the gross energy yield for fertilizer-free fertilizer variants, $\mathrm{N}_{82,5} \mathrm{P}_{45}$ and $\mathrm{N}_{120} \mathrm{P}_{52,5}$ - decreased to 48.8, 102.6 and $119.7 \mathrm{GJ}$, respectively.

It was determined that the lowest payback costs for growing crops was created by shallow singledepth shelfless main tillage (option 3), the energy factor according to the feeding backgrounds was: without fertilizers $-1.4 ; \mathrm{N}_{82.5} \mathrm{P}_{45}-2.8$ and $\mathrm{N}_{120} \mathrm{P}_{52.5}-3.2$, respectively. While for chisel tillage to a depth of $12-14 \mathrm{~cm}$ with one slit per rotation of $38-40 \mathrm{~cm}$ in the system of differentiated tillage (option 4) it acquires the maximum value and reaches 1.9, 4.1 and 4.1, respectively to power backgrounds. Thus, the cultivation of crops under these options is economically and energetically justified.

\section{CONCLUSIONS}

As a result of research, the patterns of soil processes development depending on the parameters of reclamation load were established. It is established that at the end of vegetation of crops irrigation with increased mineralization leads to deterioration of soil structure. Their content decreased the most in the system of differentiated tillage. A similar trend was observed for soil dispersion.

The most favorable conditions for the formation of yields in the experiment were created under a differentiated system of tillage with one split for crop rotation and with the introduction of increasing doses of fertilizers, which per $1 \mathrm{ha}$ of crop rotation area provided the highest productivity, for corn $15.49 \mathrm{t} / \mathrm{ha}$, followed by sorghum -8.72 , wheat winter -7.07 , and only for soybeans the best conditions this year were created for 1 option $-4.27 \mathrm{t} / \mathrm{ha}$.

The yield of gross energy of crops per 1 ha of crop rotation area depending on the methods of basic tillage and fertilizer doses in the unfertilized version and on the background of nutrition $\mathrm{N}_{82,5} \mathrm{P}_{45}$ on the yield of gross energy was the highest in the system of differentiated tillage. The energy 
coefficient in the system of differentiated tillage was the maximum and reached 1.9, 4.1 and 4.1, respectively, according to the studied feeding backgrounds.

\section{REFERENCES}

A. Singh. Soil salinization and waterlogging: A threat to environment and agricultural sustainability. Ecological indicators, 2015 - Elsevier. Volume 57, October 2015, Pages 128-130. https://doi.org/10.1016/j.ecolind.2015.04.027

Меліоровані агроекосистеми. Оцінка та раціональне використання агроресурсного потенціалу України (зони зрошення і осушення) / за ред.: М.I. Ромащенка, Ю.О. Тараріко. - Київ.; Ніжин: Видавець ПП Лисенко М.М., 2017. - 696 с.

Адаптація агротехнологій до змін клімату: грунтово-агрохімічні аспекти: колективна монографія/ за наук. Ред. С.А. Балюка, В.В. Медведєва, Б.С. Носка. Харків: Стильна типографія, 2018, 364 с.

Sveatoslav Baliuk, Lyudmila Vorotyntseva Evolution of dark chestnut steppe soil under conditions of different use and climate change Scientific Papers. Series A. Agronomy, Vol. LXI, No. 1, 2018, pages 42-25

Медведев В.В. Мониторинг почв Украины. Концепция. Итогию Задачию (2-ое пересмотренное и дополненое издание)./ В.В. Медведев - Харьков: КП «Городскаятипография, 2012. - 536 с.

Вожегова Р.А. та ін. Методика польових і лабораторних досліджень на зрошуваних землях: монографія. Херсон: Грінь Д.С., 2014. 286 с.

Ушкаренко В.О., Вожегова Р.А., Голобородько С.П., Коковіхін С.В. Статистичний аналіз результатів польових дослідів у землеробстві: монографія. Херсон: Айлант, 2013. 410 с.

Методики визначення складу та властивостей грунтів: науково-методичне видання / за ред. С.А. Балюка - Харків, 2004. - Кн. 1. - 212 с. 


\title{
OBRASCI PROCESA TLA U TAMNO SMEĐEM TLU U UVJETIMA KORIŠTENJA U UKRAJINSKOJ STEPI
}

\author{
Irina Bidnyna
}

Dr. sc., tajnica instituta, Institut za navodnjavanu poljoprivredu državne akademije poljoprivrednih znanosti

Ukrajine, Naddnipryanske, 73 483, Kherson, Ukrajina; e-mail: irinabidnina@ukr.net

\section{Olena Shkoda}

Dr. sc., voditeljica laboratorija, Institut za navodnjavanu poljoprivredu državne akademije poljoprivrednih znanosti Ukrajine, Analitički laboratorij, Naddnipryanske, 73 483, Kherson, Ukrajina; e-mail: lenashkoda79@gmail.com

\section{Anatolii Tomnytskyi}

Dr. sc., viši znanstveni suradnik, Institut za navodnjavanu poljoprivredu državne akademije poljoprivrednih znanosti Ukrajine, Odjel za navodnjavanu poljoprivredu, Naddnipryanske, 73 483, Kherson, Ukrajina;

e-mail: izz.ua@ukr.net

\section{Vera Borovik}

Dr. sc., viša znanstvena suradnica, Institut za navodnjavanu poljoprivredu državne akademije poljoprivrednih znanosti Ukrajine, Odjel za oplemenjivanje, Naddnipryanske, 73 483, Kherson, Ukrajina;

e-mail:veraborovik@meta.ua

\section{Viktor Sharii}

Doktorand, znanstveni suradnik, Institut za navodnjavanu poljoprivredu državne akademije poljoprivrednih znanosti Ukrajine, Odjel za marketing, prijenos inovacija i ekonomska istraživanja, Naddnipryanske, 73 483, Kherson, Ukrajina; e-mail: viktor.sharii@ukr.net

\section{SAŽETAK}

Kao rezultat četverogodišnjeg istraživanja, utvrđeni su obrasci razvoja procesa tla ovisno o parametrima meliorativnih zahvata. Određeno je da na kraju razdoblja vegetacije navodnjavanje usjeva visoko mineraliziranom vodom vodi k propadanju strukture tla gdje je najveća količina agregata $>10 \mathrm{~mm}$ (42.67\%) zapažena tijekom tanjuranja (sličan je trend primijećen za agregate $<0.25 \mathrm{~mm}$ ). U prosjeku, od 2016. do 2019. godine, pod utjecajem navodnjavanja, ionska izmjena vodenih ekstrakata vodi $k$ promjeni sastava saliniteta od natrij klorida - sulfata do kalcij - natrij sulfata u svim varijantama, bez obzira na promatrane čimbenike. Najpovoljniji uvjeti za stvaranje uroda u eksperimentu ostvareni su diferenciranom metodom obrade tla u jednom polju u plodoredu i uvođenjem povišenih doza gnojiva, koje je za područje plodoreda veličine 1 ha najproduktivnije, koje je za kukuruz bilo 15 t/ha, sirak - 8.72 t/ha, ozima pšenicu - 7.07 t/ha, i samo su za soju najbolji uvjeti ove godine bili dobiveni $u$ 
jednom slučaju - 4.27 t/ha. Najviša razina profitabilnosti za područje plodoreda veličine 1 ha dobivena je za prosječnu drugu varijantu norme gnojidbe $\left(N_{120} P_{52,5}\right)$ za diferenciranu metodu obrade tla-199\%, dok su se drugi sustavi obrade tla i doze gnojenja smanjile za $33-189 \%$.

Ključne riječi: procesi tla, ionski sastav soli, metode obrade tla, kvalitativna struktura tla, izmjenični kationi 
